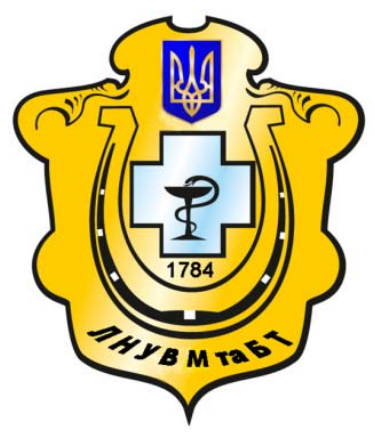

Науковий вісник Львівського національного університету ветеринарної медицини та біотехнологій імені С.3. Гжицького

Scientific Messenger of Lviv National University of Veterinary Medicine and Biotechnologies named after S.Z. Gzhytskyj

doi:10.15421/nvlvet7621

ISSN 2519-2701 print

ISSN 2518-1327 online

$\underline{\text { http://nvlvet.com.ua/ }}$

УДК 631.1.027

\title{
Вплив зовнішнього макросередовища на формування маркетингової товарної політики сільськогосподарських підприсмств
}

\author{
С.М. Ткач, I.P. Урбан \\ kafmarketungy@ukr.net \\ Львівський національний університет ветеринарної медицини та біотехнологій імені С.3. Гжицького, \\ вул. Пекарська, 50, м. Львів, 79010, Украӥна
}

\begin{abstract}
У статті розглянуто вплив зовнішнього макросередовища на формування маркетингової товарної політики сільськогосподарських підприємств. Проаналізовано, як зовнішне макросередовище для будь-якого сільськогосподарського підприємства може відкривати нові можливості або створювати нові загрози. Оскільки макросередовище є неконтрольованим, то підприємство мусить добре орієнтуватися в ньому, відстежувати його зміни та швидко реагувати на них. Якщо будьякі зміни можуть створити для сільськогосподарського підприємства сприятливіші умови для виробництва або збуту продукиії, воно повинно внести певні корективи в стратегію своєї діяльності для того, щуоб максимально використати ці умови. Зовнішні сили макросередовища несуть у собі й загрози для підприємства, тоді потрібно вживати заходів, щоб їм запобігти і зменшити їх негативний вплив. Розглянуто завдання і необхідні умови формування товарної політики сільськогосподарських підприємств. Проаналізовано основні проблеми розробки товарної політики для підприємств у сучасних

Основними ланками макросередовища, щэо тією чи іншою мірою впливають на підприємства, є: економічне, природноекологічне, інформаційне, науково-технічне, політико-правове, соиіально-культурне і міжнародне середовище.

Ключові слова: Зовнішне макросередовище, маркетингова товарна політика, товар, сільськогосподарські підприємства, економічні фактори, природно-екологічні фактори, інформачійні фактори, науково-технічні фактори, політикоправові фактори, сочіально-культурні фактори.
\end{abstract} умовах.

\section{Влияние внешней макросреды на формирование маркетинговой товарной политики сельскохозяйственных предприятий}

\author{
С.М. Ткач, И.Р. Урбан \\ kafmarketungy@ukr.net
}

\begin{abstract}
Львовский национальный университет ветеринарной медицины и биотехнологий имени С.3. Гљсицкого, ул. Пекарская, 50, г. Львов, 79010, Украина
\end{abstract}

В статье рассмотрено влияние внешней макросреды на формирование маркетинговой товарной политики сельскохозяйственных предприятий. Проанализировано, как внешняя макросреда для любого сельскохозяйственного предприятия может открывать новые возможности или создавать новые угрозы. Поскольку, макросреда является неконтролируемой, то предприятие должно хорошо ориентироваться в ней, отслеживать изменения и быстро реагировать на них. Если какие-либо изменения могут создать для сельскохозяйственного предприятия благоприятные условия для производства или сбыта продукиии, оно должно внести определенные коррективы в стратегию своей деятельности для того, чтобы максимально использовать эти условия. Внешние силь макросреды несут в себе и угрозы для предприятия, тогда нужно принимать меры, чтобы предотвратить и уменьшить их негативное влияние. Рассмотрены задачи и необходимые условия формирования товарной политики сельскохозяйственных предприятий. Проанализированы основные проблемы разработки товарной политики для предприятий в современных условиях.

\section{Citation:}

Tkach, S., Urban, I. (2017). Effect of external macro environment on the formation of marketing commodity policy agricultural enterprises. Scientific Messenger LNUVMBT named after S.Z. Gzhytskyj, 19(76), 108-111. 
Главными звеньями макросреды, которые в той или иной степени влияют на предприятия, являются: экономическая, естественно-экологическая, информационная, научно-техническая, политико-правовая, социально-культурная и международная среды.

Ключевые слова: внешняя макросреда, маркетинговая товарная политика, товар, сельскохозяйственные предприятия, экономические факторы, природно-экологические факторы, информационные факторы, научно-технические факторы, политико-правовые факторы, сочиально-культурные факторы.

\title{
Effect of external macro environment on the formation of marketing commodity policy agricultural enterprises
}

\author{
S. Tkach, I. Urban \\ kafmarketungy@ukr.net \\ Lviv National University of Veterinary Medicine and Biotechnologies named after S.Z. Gzhytskyi, \\ Pekarska Str., 50, Lviv, 79010, Ukraine;
}

\begin{abstract}
The article discusses the impact of the external macro environment for the formation marketing commodity policy agricultural enterprises. On the analyzed both external macro for any agricultural enterprise can open new opportunities and create new threats. Since, then the macro is uncontrolled enterprise should be guided well in it, it track changes and react quickly to them. If any changes which may create for the agricultural enterprises more favorable conditions for the production or marketing, it must make definite adjustments in the strategy of its activities, in order to make the most of these conditions. External power macro and carry a threat to the company, whereas one should take measures to prevent and reduce the negative impact on them. The problem and the necessary conditions of the commercial policy of agricultural enterprises. The basic problems of development of commercial policy for businesses and current conditions. Soundly the necessity of forming marketing commodity policy agricultural enterprises, taking into account the needs and behavior of consumers, promote agricultural products on the market.

The main link macro environment that to some extent affect are: economic, natural and environmental, information, scientific, technical, political, legal, socio-cultural and international environment.
\end{abstract}

Key words: macro environment, marketing, scientific factors, political and legal factors, information, socio-cultural factors.

\section{Вступ}

На даний момент в Україні для будь-якого сільськогосподарського підприємства основним є ефективне виробництво та стабільне отримання прибутку. Для успішного розвитку сільськогосподарської підприємницької діяльності необхідно звернути увагу на умови ринкового середовища: попит, конкурентів, економічні та політично-правові фактори життя держави. Маркетинговий підхід дозволяє виробити конкретні цілі, стратегії, певну тактику поведінки сільськогосподарського підприємства на ринку та підвищити дохід. Ефективну діяльність сільськогосподарських підприємств багато в чому визначає їх здатність виходу на ринок 3 асортиментом товарів і послуг, що користуються стійким попитом у споживачів. Відповідно виникає необхідність формування маркетингової товарної політики сільськогосподарських підприємств, яка враховує потреби та поведінку споживачів, систему просування сільськогосподарської продукції на ринок.

При формуванні та удосконалені маркетингової товарної політики виникає низка проблем. Сільськогосподарське підприємство при здійснені своєї діяльності не є ізольованим, а контакує із зовнішнім середовищем, яке представлене відомими силами, що діють за його межами. Ці сили 3 різним ступенем активності безпосередньо або опосередковано впливають на життя підприємства, зачіпають його інтереси. На одні сили підприємство може певною мірою впливати, намагаючись змінити їх дію в своїх інтереcax, проте інші $є$ повністю незмінними. Незважаючи на неоднаковий характер дії зовнішніх сил, підприємство не може не рахуватися 3 ними в процесі своєї діяльності, оскільки вони призведуть до негативних наслідків. При формуванні маркетингової товарної політики обов'язково потрібно звертати увагу та досліджувати вплив зовнішнього макросередовища підприємства.

\section{Результати та їх обговорення}

Маркетингову товарну політику не можна відокремити від зовнішнього маркетингового середовища сільськогосподарського підприємства. Щоб забезпечити стійке та стабільне становище на ринку, підприємство має швидко та гнучко реагувати на зміни зовнішнього середовища (Kravtsiv, 2014). Зовнішнє середовище - сукупність факторів, що впливають більш масштабно на діяльність підприємства та інші елементи мікросередовища, - це економічні, політикоправові, природно-кліматичні, демографічні та інші умови (Dichenko, 2016).

Маркетингове середовище постійно змінюється: ринкові можливості й загрози виникають, змінюються й зникають, тому для підприємства є дуже важливим, вчасно розпізнавши ринкові можливості й загрози, розвивати можливості та знешкоджувати загрози (Bondarenko and Bondarenko, 2011). В цьому контексті аналіз впливу макросередовища на маркетингову діяльність підприємства набуває неабиякого значення, тим паче, якщо враховувати сучасний стан вирішення цієї проблеми (Shtefanych and Diachuk, 2013).

Якщо на ринку (або в зовнішньому середовищі) для сільськогосподарського підприємства виникатимуть загрози, товарна політика повинна їх максимально враховувати 3 метою скорочення можливих втрат, але не відступаючи від головних принципів і 
положень стратегії. Іншими словами, товарна політика має бути як постійною (непорушною) у своїх фундаментальних установках, так і адаптованою до змінних впливів зовнішнього середовища. У цьому і полягає сутність діалектики товарної політики сільськогосподарського підприємства (Dichenko, 2016).

Для того, щоб адаптуватися до макросередовища, перед підприємством стоїть основне завдання: постійно вивчати економічні, політико-правові, природно-кліматичні, демографічні, науково-технічні та фактори культурного оточення. Їхній вплив на маркетингову товарну політику сільськогосподарських підприємств в основному залежить від характеру i сили впливу на господарську діяльність.

Економічні фактори зовнішнього маркетингового макроекономічного середовища сільськогосподарських підприємств відносяться до неконтрольованих. Основними економічними факторами є рівень інфляції або дефляції, ступінь розвитку конкурентного середовища, рівень зайнятості, податкова політика, динаміка і співвідношення цін на сільськогосподарські товари тощо. В узагальненому вигляді воно може бути визначене через купівельну спроможність населення. Насиченість ринку сільськогосподарською продукцією та зростання купівельної спроможності населення $є$ для аграрних підприємств певним сигналом до збільшення виробництва передусім дорогих високоякісних товарів. Відповідно до цього сільськогосподарські підприємства можуть залучати додаткові ресурси, знімати з консервації частину земельних ділянок, використовувати нові досягнення агрономічної і зоотехнічної науки для підвищення врожайності культур і продуктивності тварин. I навпаки, коли купівельна спроможність знижується за рахунок зменшення доходів населення, то через зростання безробіття обсяги продажу сільськогосподарської продукції зменшуються. При цьому підвищуються процентні ставки на кредит, скорочується інвестиційна діяльність. Через нееластичність цінового попиту на сільськогосподарські товари це зменшення відбувається повільніше, ніж на промислові товари, але це не означає, що аграрні підприємства не повинні реагувати на зниження купівельної спроможності населення. Залежно від обставин ця реакція може бути різною - від швидкого скорочення виробництва певних видів продукції до виходу підприємства на нові ринки та збуту своїх товарів, в тому числі і міжнародні. Аналізуючи економічне середовище, підприємству необхідно врахувати диференціацію доходів населення.

При вивчені кліматичних факторів підприємство стикається з сезонним попитом на сільськогосподарські товари, які є практично некерованими і залежить від кліматичних умов регіону. Але врахування саме кліматичних факторів дозволяє підприємству за рахунок зрушень сезонів розширити обсяги продажів у різних регіонах України , що є актуальним для товарів сезонного характеру та сільськогосподарських підприємств. Також для маркетингової товарної політики непередбачуваними $\epsilon$ природно-кліматичні умови: розораність земель, кліматичні особливості, родючість грунту. Навіть у Польщі чи Словенії, де є високорозвиненим сільське господарство, де застосову- ються інноваційні технології виробництва, результати від діяльності сільськогосподарських підприємств непередбачувані. Залежно від змін температурного режиму, посухи, повені чи інших природнокліматичних умов сільськогосподарські підприємства $\epsilon$ порівняно ризикованим бізнесом для інвесторів. На товарну політику впливають природно-кліматичні умови, це доводить факт, що в рослинництві протягом року підприємство отримує продукцію 1-2 рази, а робота триває протягом цілого року. Підприємству потрібно здійснювати детальне, ефективне планування та реалізацію товарів 3 максимальною вигодою.

Науково-технічні фактори макросередовища також займають певне місце у формуванні розвитку маркетингової товарної політики сільськогосподарських підприємств. Підприємство повинно своєчасно враховувати та застосовувати нові тенденції і досягнення науково-технічного прогресу. Коли підприємство не реагуватиме на вплив цього фактора, воно буде приречене на стагнацію і банкрутство. Підприємство має приймати обгрунтовані рішення про доцільність та можливість впровадження у виробництво нових видів техніки і нових технологій, забезпечуючи таким чином конкурентоспроможність своїх товарів та доходність від їх реалізації. При впровадженні іновацій підприємствам варто бути обережними в тому розумінні, щоб сільськогосподарська продукція не зашкодила здоров'ю населення.

Будь-яке підприємство стикається у своїй господарській діяльності з політико-правовими факторами. Політико-правові фактори складаються 3 системи законів та інших юридичних актів, які регламентують господарську діяльність підприємства, а також систему політико-правових інститутів, що виробляють ці правові документи і контролюють їх виконання. Активне та вміле застосування положення основних законів та законодавчих актів дає змогу підприємству уникнути порушень, які загрожують штрафними санкціями аж до заборони займатися виробничою діяльністю взагалі.

У розвинутих країнах Західної Свропи та США, особливу роль відіграють політичні партії і громадські рухи в захисті інтересів та прав громадськості як на загальнонаціональному рівні, так і на рівні окремих адміністративних територій. У своїй діяльності сільськогосподарські підприємства повинні зважати на це при плануванні товарів з новими якісними характеристиками та при розробці стратегій маркетингової діяльності.

Соціально-культурне середовище формується під дією демографічних процесів і змін культурноосвітнього рівня населення. Підприємство у своїй діяльності повинно враховувати зміни в структурній будові населення за віковими групами, а також зміни в культурі харчування, оскільки це зумовлює зростання попиту на одні види сільськогосподарської продукції та зменшення його на інші. Збільшення (зменшення) кількості населення впливає на товарну політику підприємства, оскільки повинні збільшуватися (зменшення) обсяги виробництва приблизно такими ж темпами, якими зростає кількість населення. 
Несвоєчасне вивчення та врахування соціальнокультурних факторів підприємством може загрожувати йому втратою позицій на ринку, зменшенням обсягу виробництва та зниженням його ефективності.

\section{Висновки}

Для ефективного функціонування підприємства в умовах мінливого макросередовища необхідним $\epsilon$ постійне удосконалення маркетингової товарної політики сільськогосподарських підприємств. А це неможливо без розуміння та усвідомлення актуальних умов іiі формування. Основні аспекти товарної політики сільськогосподарських підприємств приймаються під дією множини умов та чинників макросередовища. Зовнішнє макросередовище для будь-якого сільськогосподарського підприємства може відкривати нові можливості або створювати нові загрози. Макросередовище $\epsilon$ неконтрольованим, але підприємство мусить добре орієнтуватися в ньому, відстежувати його зміни та швидко реагувати на них. Якщо будьякі зміни можуть створювати для сільськогосподарського підприємства сприятливіші умови для виробництва або збуту продукції, воно повинно внести певні корективи в стратегію своєї діяльності для того, щоб максимально використати ці умови. Зовнішні сили макросередовища несуть у собі й загрози для підприємства, тоді потрібно вживати заходів, щоб запобігти негативному впливу і зменшити його.

Перспективи подальших досліджень. Товарна політика передбачає певний курс дій товаровиробника або наявність у нього наперед обдуманих принципів поведінки. Вона покликана забезпечити прийняття рішень стосовно формування асортименту й управління ним; підтримання конкурентоспроможності товару на певному рівні; знаходження для товарів оптимальних товарних ніш (сегментів); розробки та реалізації стратегії упаковування, маркування, обслуговування товарів.

Отже, в умовах ринкової економіки сільськогосподарським підприємствам необхідно адаптувати товарну політику й товарний асортимент так, щоб вони відповідали потребам споживачів та водночас сприяли збільшенню прибутковості підприємства. Необхідно, щоб кожне підприємство орієнтувалося на стійкий соціально-економічний розвиток і на повне використання якісних чинників економічного зростання, які б забезпечували виробництво високоякісної продукції, виконання робіт і надання послуг для задоволення потреб ринку та отримання максимально можливого позитивного фінансового результату.

\section{Бібліографічні посилання}

Bondarenko, V.M., Bondarenko, L.M. (2011). Sutnist, struktura ta doslidzhennia marketynhovoho seredovyshcha diialnosti pidpryiemstv APK. Zbirnyk naukovykh prats VNAU. 2(53), 3, 166-172 (in Ukrainian).

Harkavenko, S.S. (2002). Marketynh: [pidruchnyk]. K.: Libra (in Ukrainian).

Dichenko, A.L. (2016). Umovy formuvannia marketynhovoi tovarnoi polityky silskohospodarskykh pidpryiemstv. AHROSVIT. 7, 39-43 (in Ukrainian).

Kravtsiv, S.M. (2014). Formuvannia marketynhovoi tovarnoi polityky silskohospodarskykh pidpryiemstv ta shliakhy yii udoskonalennia. Visnyk LNUVMBT imeni S.Z. Gzhytskoho. 16, 2(59), 104-109 (in Ukrainian).

Shtefanych, D., Diachuk, O. (2013). Analiz vplyvu zminy marketynhovoho seredovyshcha na marketynhovu diialnist pidpryiemstva. Visnyk TNEU. 2, 44-53 (in Ukrainian).

Стаття надійшла до редакиії 2.03.2017 